\title{
11. Social partners and the world of work in Poland: Between East and West Dominika Polkowska
}

\section{INTRODUCTION}

With a population of about 38 million, Poland is the largest of the new European Union (EU) member states. Its geographical location means that it is exposed to processes and phenomena not found elsewhere (for example, its eastern border is an external border of the EU). Since Poland's accession to the EU in 2004, the national labour market has experienced large-scale outward and inward labour migration. In his study, Jan Czarzasty (2019, pp. 465-82) observes that 'one of the key features ... is post-socialist path dependency, which has led to the creation of a hybrid form of capitalism labelled the "dependent market economy",

The main purpose of this chapter is to present the positions of the social partners (employers' organizations and trade unions) regarding the future of the labour market in Poland. Secondly, it examines its most important problems. Thirdly, it presents examples of good practices among the social partners as they seek to strengthen their role in social dialogue. Another aim is to facilitate mutual understanding between the individual parties to social dialogue (which converge on many points), which in turn will strengthen general social dialogue in Poland.

This chapter presents the standpoint of the social partners (employers' organizations and trade unions) in Poland on the three most pressing issues concerning the future of work: the representativeness of the social partners, the autonomy of the social partners, and digitalization, as well as their general assessment of social dialogue in the country.

The most current issue in the context of the changes taking place in the Polish labour market is economic migration. Polish employers face a severe labour shortage and the problem is increasingly being solved by employing migrants from the countries across Poland's eastern border, mainly Ukraine. This chapter also includes the social partners' opinions on economic migrants in Poland.

In addition, I present the key labour market indicators, the Social Dialogue Council and the social partners' attitude to it, as well as two case studies. The first case study is devoted to the activities of the Sworn Translators' Trade Union in Poland as an example of an organization whose members are in the same occupation but are mainly self-employed. The second concerns social dialogue in Company A in the e-services sector.

In section 2, I present the context of the study, that is, the current characteristics of the labour market in Poland. Section 3 then presents basic information on social dialogue and its role, and section 4 discusses significant facts about trade union density and 
the membership rate of employers' organizations in Poland. In section 5 I present the national story of migration and migrant workers in Poland. The main challenges in the new world of work faced by trade unions and employers' organizations are the core of sections 6 and 7. The case studies are described in section 8. Section 9 looks at the central public administration's view of, and role in, social dialogue. Some conclusions are offered in section 10 .

\section{CONTEXT: BASIC FACTS ABOUT THE POLISH LABOUR MARKET}

According to the data provided by Statistics Poland (2019), recent years have seen an intensification of positive trends in the Polish labour market: employment has been increasing constantly and unemployment falling. In 2017, the proportion of people aged 15 years or over who were economically active was 56.2 per cent, 95.5 per cent of whom were employed. The unemployment rate was 4.5 per cent, the lowest since the $1990 \mathrm{~s}$, when it first began to be systematically measured, as was the number of unemployed registered with labour offices (slightly over a million at the end of 2017).

Other positive phenomena include the highest number of job vacancies since 2010 (which may also be the result of a mismatch between supply and demand), at around 118 000 (mainly in manufacturing, trade and construction). We can also observe a systematic increase in pay.

This generally positive picture of the labour market is not, however, devoid of threats. One of these threats is the persistent significant difference between the economic activity of women and of men. In 2017, the male employment rate was 62.2 per cent, but female rate only 45.8 per cent. This has been the case (despite the increase in both indicators) for years. There are also considerable differences in economic activity depending on age, education and place of residence.

A number of other labour market indicators (for 2017) are also of interest:

- part-time employment - 1180000 people, that is, 7.2 per cent of the employed, 10.6 per cent for women and 4.4 per cent for men;

- time-related underemployment - 1.4 per cent of those employed;

- temporary employment - 3340000 people, that is, 25 per cent of those employed;

- civil-law contracts -3.4 per cent of those employed (no employment contracts);

- undeclared work (estimated) - 5.4 per cent of the working population;

- self-employed - 17.5 per cent of the working population.

In summary, although the situation on the Polish labour market is relatively good (low unemployment rate of 4.5 per cent and increasing employment), we still find some negative points, such as the very high rate of temporary employment ( 25 per cent of the working population), a persistently high proportion of civil-law contracts (3.4 per cent of all those employed, at 1.2 million people), which is particularly unfavourable from employees' viewpoint as these arrangements amount to 'no employment contracts' that deprive them of their entitlements. Finally, there are also very high estimates of undeclared work, at 5.4 per cent of the working population. 
The high rate of temporary employment, as well as the high proportion of civil-law contracts (especially bogus self-employment) represent the biggest challenge for the Polish labour market. The next biggest challenge is labour shortages, which could be overcome with a proper migration policy and migrant workers. Employers need more workers to maintain their productivity and development. The most easily available jobs are in manufacturing, trade and construction; they are mainly simple jobs, not requiring special skills or qualifications. Polish workers are generally not interested in this work, mainly owing to the low wages. That is why the migrant workers are indispensable. Trade unions and employers' organizations should, within the framework of social dialogue, seek possible solutions that will be attractive for both.

\section{GENERAL INFORMATION ON SOCIAL DIALOGUE IN POLAND: THE SOCIAL DIALOGUE COUNCIL AND ITS ROLE}

The Social Dialogue Council (Rada Dialogu Społecznego, hereafter RDS) was established by the President of the Republic of Poland on 22 October 2015, pursuant to the Act on the Social Dialogue Council and Other Institutions of Social Dialogue. ${ }^{1}$ The RDS is a forum of tripartite dialogue involving representatives of employers, of employees and of government. Apart from this central body, there are also Regional Social Dialogue Councils. The RDS replaced the Tripartite Commission for Social and Economic Affairs (Trójstronna Komisja do spraw Społeczno-Gospodarczych), established in 1994.

Article 1 of the Act specifies three principal objectives of the RDS:

1. To ensure favourable conditions for socio-economic development and to enhance the competitiveness of the Polish economy, as well as social cohesion.

2. To implement the principle of social participation and solidarity with regard to employment relations.

3. To work to improve the quality of developing and implementing socio-economic policies and strategies and build social consensus on these issues by holding transparent, substantive and regular dialogue between workers' and employers' organizations and the government.

The activities of the RDS are supposed to support social dialogue at all levels of territorial government. The responsibilities of the workers' and employers' organizations, which are the parties to the council, focus on expressing opinions and taking positions, as well as on giving opinions on draft guidelines for proposed and draft legal acts.

The RDS is composed of representatives of the government, representative trade unions and representative employers' organizations. The three trade unions considered representative at the national level are: Solidarity (NSZZ Solidarność), the All-Poland Alliance of Trade Unions (Ogólnopolskie Porozumienie Związków Zawodowych, OPZZ) and the Trade Unions Forum (Forum Związków Zawodowych, FZZ). The representative employers' associations, in turn, include: the Employers of Poland (Pracodawcy Rzeczypospolitej Polskiej), the Polish Confederation Lewiatan (Konfederacja Lewiatan), the Polish Crafts Association (Związek Rzemiosła Polskiego, ZRP), the Business Centre 
Club (BCC) and the Union of Entrepreneurs and Employers (Związek Przedsiębiorców i Pracodawców, ZPP). Finally, the government representatives are members of the Council of Ministers and other representatives nominated by the Prime Minister.

Unfortunately, representatives of the trade unions and the employers' organizations have considerable reservations about the role of the RDS.

What are representative trade unions in Poland busy doing? What do they devote a lot of their time and energy to? To expressing their opinion on draft acts and regulations. Those things which they do under Article 19 of the Act on Trade Unions - take about 80 per cent of the time. And this begs the question of whether these proportions shouldn't be different. Do we really have to give our opinion on everything? Wouldn't it be more important for us to sign more collective agreements? These are the questions that the leaders and the Presidium [of the National Commission] will have to face. (Representative of trade union, hereafter TU)

Over almost four years, the RDS has adopted 34 resolutions, ${ }^{2}$ mainly concerning the approval of its annual documents (reports on operations, reports on the implementation of annual financial plans by the Office of the Council, and plans of operations), setting up teams dealing with particular issues, and changes in membership of the council.

On the basis of its annual reports on operations, it can be assumed that members of the council are aware of changes currently under way in the world of work. This is also apparent from the key points on its agenda for 2019 that include such issues as the future of work in Poland, and professional qualifications in the context of the changing needs of economy and the labour market. The council also considers it necessary to strengthen the existing mechanisms of social dialogue and to increase the participation of social partners in the legislative process.

In the same period, the parties to the RDS adopted 82 resolutions. ${ }^{3}$ Although none of them referred explicitly to the future of work and future roles of the social partners, there were several that directly or indirectly concerned labour market issues (for example, Resolution No. 9, concerning a proposed draft amendment to the Act on the Minimum Wage, Resolution No. 13, concerning a proposed draft amendment to the Act on Employment Promotion and Labour Market Institutions, and Resolution No. 18, concerning a proposed draft amendment to the Labour Code).

According to its annual report on operations for $2017,{ }^{4}$ the RDS accomplished the objective concerning the adaptation of workers' skills to the needs of the labour market. The proposed solutions were included in Resolution No. 48, adopted by the parties to the RDS, on recommended changes in the national education system in the domain of vocational education.

However, trade unions and employers' organizations both give a negative assessment of the work of the Social Dialogue Council. At the formal level, the process operates as it should, and there are no barriers or obstacles to social dialogue. However, the reality is entirely different: most view social dialogue conducted within the framework of the RDS as a façade:

Technically speaking, it all looks perfect. There is proper legislation in place and our representation is guaranteed. But there is one question that arises here: how far is the Council really ignored? I'll give you one perfect example. The responsibilities of the RDS include making a decision on the level of increase of the minimum wage. That's something guaranteed in the legislation; it's guaranteed that the parties to the Council give their opinions, that there is a whole 
procedure for what happens if social partners don't agree and so on. And what's the use of all that if the government simply issues a statement declaring an increase of the minimum wage in the media? They didn't even pretend to hold any social dialogue on this issue. (Representative of employers' organization, hereafter EO)

Under these circumstances, employers receive a clear signal that their opinion will not be considered at all, which may foster a sense of being ignored by the government. To some extent, this also stems from the choice of government representatives who are involved in the work of the RDS:

It should be a rule that government representatives in the Council should include a minister. If we see that the officials representing the government are increasingly lower in rank - let's be fair, they are often very competent, but they have no powers to make decisions. This situation weakens the role of social dialogue and of the RDS. (EO)

Currently, the role of social dialogue depends entirely on how it is approached by the government. The quality of social dialogue can best be seen by looking at how the government (regardless of the party in power) treats the outcomes of the decision-making process:

If we have gone through a long process, the social partners have reached agreement and the government finally ignores all that, the situation is as follows: in formal terms, a certain process has taken its course, but in fact this whole work is utterly pointless; it has no bearing on reality at all. On occasion the government should also consult the RDS on some issues [such as the minimum wage - DP], but they don't. ${ }^{5}$ (OE)

\section{TRADE UNION DENSITY AND MEMBERSHIP OF EMPLOYERS' ASSOCIATIONS IN POLAND}

At the time of writing, there are three trade unions and five employers' associations that are considered representative at the national level. The former are Solidarity (NSZZ Solidarność), the All-Poland Alliance of Trade Unions (Ogólnopolskie Porozumienie Związków Zawodowych, OPZZ) and the Trade Unions Forum (Forum Związków Zawodowych, FZZ); and the latter are the Employers of Poland (Pracodawcy Rzeczypospolitej Polskiej), the Polish Confederation Lewiatan (Konfederacja Lewiatan), the Polish Crafts Association (Związek Rzemiosła Polskiego, ZRP), the Business Centre Club (BCC) and the Union of Entrepreneurs and Employers (Związek Przedsiębiorców i Pracodawców, ZPP). All these organizations are represented in the Social Dialogue Council.

According to the data provided by the Central Statistical Office (GUS), in 2018 there were 400 employers' organizations and 12500 trade union organizations at different levels. Most of the latter were those active in particular enterprises or institutions, or parts or branches (78.1 per cent) thereof, followed by inter-enterprise trade union organizations (19.5 per cent). There were also federations and confederations of trade unions with local or industry branches, as well as uniform trade unions; their total number was about 300 (2.3 per cent). The smallest category was trade unions of individual farmers ( 0.1 per cent). ${ }^{6}$ In the period between 2014 and 2018, the number of employers' 
organizations increased by 10 per cent and the number of active trade unions decreased by 2.9 per cent. In 2018, the proportion of trade union organizations affiliated to a trade union centre representing workers in the Social Dialogue Council was 82.6 per cent, and the corresponding figure for organizations representing employers was 22.2 per cent.

Trade unions and employers' organizations both reported problems. In the former, these were problems caused by law and legal procedures (33.1 per cent) and difficulties in dealing with employers (30.8 per cent); in the latter, problems were caused by law and legal procedures (45.8 per cent) and in dealing with public administration (33 per cent). The last challenge both for trade unions and employers' organizations was related to insufficient number of members (24.7 per cent and 19.9 per cent, respectively, reported these issues, respectively).

In 2018, the trade unions had a membership of 1.5 million, which amounts to 4.9 per cent of the adult population, and to 16.3 per cent of workers employed on the basis of employment contracts in enterprises employing more than nine people. ${ }^{7}$ Employers' organizations, in turn, had a membership of 19100 entities.

As regards the structure of trade union membership, the most numerous were those working in education (23.2 per cent), followed by public administration and defence (13.9 per cent), manufacturing (12.7 per cent), and human health and social work (18.5 per cent). Members of employers' organizations were to be found in the following sectors: human health and social work (18.5 per cent), manufacturing (10.3 per cent), services $(9.8$ per cent) and trade (9.2 per cent).

\section{MIGRATION AND MIGRANT WORKERS: A NATIONAL STORY}

Poland is both an emigration and an immigration country (Kałuża-Kopias 2014): while many Poles have moved to the United Kingdom and Germany (Kostrzewa and Gudaszewski 2018), the country has received a large number of migrants, mainly from Ukraine (Grzymała-Kazłowska 2013). Since Poland's accession to the EU in 2004, there have been considerable changes in the employment policy towards foreign nationals. For Ukrainian, Armenian, Belarusian, Russian, Moldovan and Georgian citizens migrating to Poland, an employer's statement declaring the intention to employ a foreigner is often sufficient for the Polish authorities (Kałuża-Kopias 2014). Changes in legal regulations introduced in 2017-18 made it even easier for holders of Ukrainian passports and some other nationals to cross the border and work in Poland. As a consequence, according to some estimates, the number of Ukrainian migrants working in the country may be as high as 3 million and continues to increase (Lis 2017). Although these migrants have usually taken low-paid jobs in industries such as agriculture or construction, the situation is rapidly changing owing to the growing demand for professionals in the information technology (IT) and financial sectors (Grabowska-Lusińska et al. 2011).

Industries hiring foreigners in Poland are, for the most part, those with low prestige that most often offer the minimum wage for regular employees and simple, monotonous work, very often in difficult conditions. In these industries, the shortage of manpower is particularly apparent. Polish workers do not want to accept the minimum wage in the 
construction or service sectors, for example. This work often does not even require a good command of Polish. As far as the form of employment is concerned, non-employee employment predominates (civil law contracts) (Polkowska and Filipek 2020, p. 567).

Affected by workforce shortages, central and eastern European economies are benefiting from ongoing migration from Ukraine (Fedyuk and Kindler 2016). Cultural and geographical proximity make the region the first choice for workers leaving that country. However, the recent wave of migration from Ukraine has often had a transitional, circular or seasonal character (Molodikova and Yudina 2016). The current Polish migration policy is focused mainly on short-term needs, and there is no long-term vision of the role and significance that Ukrainians might play in the Polish economy. Also, no changes in this respect are to be expected in near future, contrary to the wishes of the social partners in particular.

According to the Organisation for Economic Co-operation and Development (OECD), in 2017 Poland had an inflow of labour migrants numbering 1.1 million, the highest in the OECD (see Figure 11.1). ${ }^{8}$

In 2017, Poland was not only the top temporary ${ }^{9}$ labour migration destination among OECD countries, but also the third largest, after the United States and Germany, for total number of migrants. Most of those who arrived in the country were temporary labour migrants (OECD 2019).

When asked about labour migration, social partner representatives replied as follows:

From the point of view of the trade unions, it's a really difficult issue. First of all, because the unions in Poland aren't active enough when it comes to recruitment. Why? Because everyone is convinced that it's a temporary situation. In the past there were only Poles on the national labour market here and according to many people that's a normal situation. And what we have here now is a deviation from that normal state, and things will get back to normal at some point. (TU)

Inflow (2017), in thousands

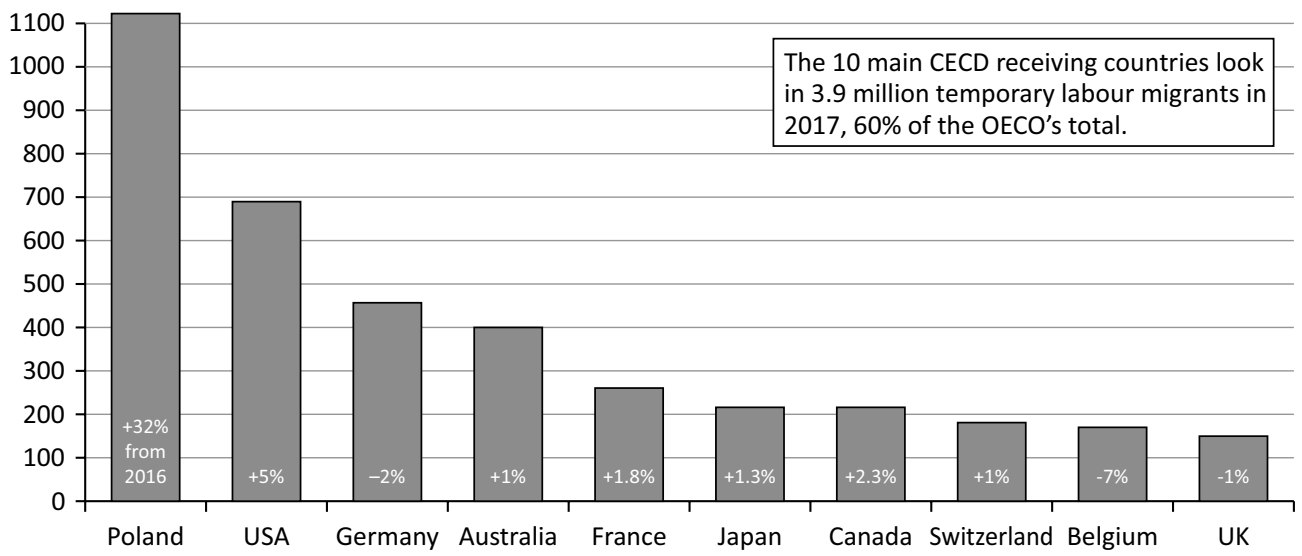

Source: OECD (2019).

Figure 11.1 Inflows of temporary labour migrants: ten main OECD receiving countries, 2017 
The government does not make the situation any easier. There is no official document that outlines the principles of migration policy. Indeed, migration is not a topic under discussion, and any debate on this issue in Poland is extremely difficult.

And here we come back to the argument that it's a transitional situation - it wasn't necessarily a good decision to let all those Ukrainians in, but they will surely go back as soon as the situation in Ukraine improves, or they will go to Germany. Of course, we are absolutely against any kind of discrimination against them. But this doesn't mean we are really making an effort to help them organize; why should we, really? They will be gone soon, anyway. (TU)

The other trade union representative had a very similar view of the situation:

We strive for a consistent migration policy in Poland - there isn't one in place at all. We want to know what Poland as a country wants when it comes to labour migration. Are we opening up or closing? What we want is a balanced migration policy that would take into consideration the reality of the Polish labour market and local workers, but of course wouldn't close the borders at the same time; a policy that would also involve integration and adaptation programmes. I'm against special regulations for migrant workers. We want to get to a point when all workers are covered by the same standards. (TU)

In this representative's opinion, the problems started when eligibility requirements and entry procedures for citizens of the six countries of EU Eastern Partnership were simplified. Under considerable pressure from employers, who insisted they suffered from a shortage of manpower, the Polish labour market was gradually opened to non-EU citizens (mainly Ukrainians).

As a result, we've got to a point where there are two million statements [declaring the intention to employ a foreign citizen] a year. This comes as a combined result of several problems which stem from the fact that we don't have a migration policy; and the current government doesn't want to develop one. (TU)

According to this informant, one factor that contributes to the expansion of the informal sector is the inefficiency of the public administration, which is unable to process such a vast quantity of documentation; it cannot offer competitive salaries and it is understaffed.

The situation of economic migrants on the Polish labour market is thus clearly worse than that of local workers. In a number of sectors (for example, construction, restaurants and catering, care services and agriculture) foreigners earn less than Polish workers, and are often employed without any contract and thus without any guarantees of their rights.

The key issue here is the temporary work agencies. While the largest agencies play by the rules, smaller agencies - often run by self-employed entrepreneurs working on their own - tend to disappear when affected by solvency issues, and contacting them is often problematic.

When analysing the situation of economic migrants in Poland, note that, according to union activists, the informal sector keeps growing. Although the scale of the problem is impossible to gauge, it is apparent that a considerable proportion of migrant workers work without contracts: 'There is obviously a large-scale informal sector; absolutely no one has any control over it. It's a massive opportunity for abuses of all sorts' (TU). 
One way to tackle the problem would be to inform prospective migrants of their rights while they are still in Ukraine. However, this idea does not seem to be widely supported. A better suggestion might be to employ members of ethnic communities to help their compatriots working in Poland, which is a model adopted in Germany:

I would really like to see a network of information and advice centres with people from ethnic communities working there, so that migrants could sort things out in their own language. It's a German model that's worth copying. But this requires funding because such staff would be employed by trade unions. We can't afford that. (TU)

In general, the trade unions do not address issues related to migration policy, and they do not even aspire to initiate a debate on economic migrants. As viewed by the main trade union centres, everything has already been regulated and there is no room for improvement. Any new solutions in this respect, such as opening the labour market to new categories of foreign nationals, would not be welcome.

Consequently, any attempts by trade unions to organize foreign nationals working in Poland are praiseworthy. One that attempting to do so is the Inter-Enterprise Trade Union of Ukrainian Workers in Poland (Międzyzakładowy Związek Zawodowy Pracowników Ukraińskich w Polsce), affiliated to the OPZZ.

This union is different from typical trade unions. It's a bit like an advice or information centre. The question of membership is very fluid there; it's about dealing with particular problems: from finding a new job, through help in finding accommodation, to information about schools. It's more like an association. Although they focus on workers' issues, of course. The head of the union cooperates closely with the National Labour Inspectorate (PIP), the Border Guard and the public prosecution service. Because there are cases resembling forced labour when it comes to Ukrainians in Poland. (TU)

It is interesting to consider why this union was established. This largely stems from Ukrainian workers being reluctant to join the existing unions in Polish enterprises where they work. They have low trust in trade unions in Ukraine and transpose this attitude to Poland. Their outlook can only change over time, but the process is even more difficult considering that they have to circulate between Poland and Ukraine owing to current legal regulations.

This type of activity is worth developing. Taking into account that the number of migrant workers in the Polish labour market is still increasing, there is a need to extend this type of initiative. There is a chance not only for the OPZZ but for all trade unions, to take migrant workers (not only from Ukraine) under their wing. However, it might be also a challenge for employers' organizations: they should uphold equal treatment of migrant and local workers, especially equal pay.

Another problem here is the passive attitude of the state: 'The problem is that the government doesn't want to talk about it. Any attempt to regulate this area ends up in proposed legislation being thrown out, or in the dismissal or resignation of the minister responsible for this issue' (TU).

Let us now turn to how the issue of economic migrants in Poland is viewed by employers. In their opinion, migration fills a gap in the labour market: some local workers are not ready to accept certain jobs, mainly simple ones, which do not require particular skills and are low-paid or involve work in difficult conditions. These positions are often filled 
by migrants, particularly from Ukraine. Employers stress cultural proximity between the two countries, thanks to which they integrate very well in Poland. This factor is very important from the employers' point of view.

They play an important role. Apart from working in jobs that Poles don't want to do, and which are important for the survival of some firms, they also do something extra: they buy goods here, they fuel our economy. They play a very important role. To some extent, the shortage of workers can be dealt with by automation but there will always be work that has to be done by people. In this situation, economic migrants are our lifeline. (EO)

However, not all employers are honest and not all of them treat migrants properly. There are a considerable number of cases of abusive and illegal practices:

There is a problem. Some employers - and we have to beat our own chest here - don't treat those workers honestly. We [as an employers' organization] don't approve of such practices because they are against the law. Secondly, they affect competition. If enterprises employ migrants illegally, their costs of manpower are much lower and that's unfair on those who play by the rules. We keep monitoring the situation as far as we can. (EO)

The most acute problem faced by employers is the lengthy administrative procedure required in the case of foreign workers. Employers' organizations view it as their role to put pressure on public administration to apply procedures in a more timely fashion:

A lot of people from our member enterprises contact us about the problems they have when they want to employ foreign nationals: they have problems with government administration at the regional level when they apply for work permits. It takes a really long time, even a few months, to issue those permits. (EO)

Employers' organizations make a great effort to draw to the attention of regional authorities that procedures take too long. They make civil servants aware that the situation creates considerable problems for business. They also propose solutions, which range from employing more office staff to deal with the processing of documentation, to modifying the system of filing applications and required documents (for example, by going toward its full digitalization).

Considering that a number of business entities are entirely dependent on workers from across the eastern border, employers' organizations stress that foreign nationals are very much needed on the Polish labour market. They also stress that there is much to be done to protect their rights and to enable employers to offer them jobs according to all legal regulations. What they identify as the most serious barrier is the administrative process of issuing work permits.

The labour shortage was mentioned by all informants from employers' organizations. In their view, it can be solved only by labour migration as local workers are not interested in the kind of jobs on offer. Considering that it is the most serious barrier to the growth of their businesses, employers are very much interested in making the employment of foreign nationals even simpler. Also, since the inflow of migrants from the neighbouring countries in the east is decreasing, they more often turn their attention to migration from Asia.

Employers understand the government's concerns over security issues stemming from such a large influx of migrants. They stress that it is absolutely necessary to streamline 
the administrative legalization of their status in Poland. As it is now, the situation has reached a point at which

firms compete over migrants. At the moment, you could say that a worker is an object of desire. Firms keep looking for employees and the shortage of manpower is really serious. And so if there is an opportunity to bring over migrants, they are interested. And even once they come here not all firms are able to satisfy their employment needs. (EO)

All employers' organizations stress that the problem lies in the government administration at the regional level, which is responsible for work permits and the legalization of the status of migrants in Poland. The procedures involved take a very long time and are extremely detailed. The problem is largely attributed to the insufficient number of officials dealing with these matters directly. To some extent, the situation comes as a result of very low salaries: as part of the government administration, staff in regional offices have not had their salaries increased for several years. Consequently, sometimes people who process work permit and residence applications receive pay that is lower than that of the migrants whose applications they handle.

Finally, the informants also mentioned the issue of migration from Asia. For Asian migrants, simplified procedures concerning residence and employment status in Poland do not apply, which means that the process takes even longer. Also, the flow of workers from Ukraine is decreasing, which is attributed to better pay rates offered in Germany and Czechia. 'That's why employers are increasingly turning to people not only from Asia, but also Brazil and Argentina, for example, when it comes to IT jobs' (EO).

\section{MAIN TRADE UNION CHALLENGES IN THE NEW WORLD OF WORK}

On the basis of the official agendas of the three main trade union centres, ${ }^{10}$ it is possible to indicate the following ten key challenges in the context of the future of work in Poland:

1. The necessity of trade union revitalization, enhancing the unions and increasing their potential.

2. The segmentation of the Polish labour market and the existence of employee groups that have no stable employment - precarious workers; the proportion of people performing work on the basis of contracts other than employment contracts is stable but remains very high; the level of protection of their rights is far from sufficient.

3. Removing barriers to the employment of young people - the issue of junk contracts (the colloquial name of civil law contracts).

4. The importance of strengthening collective bargaining.

5. Migration policy - integrating migrants in the Polish labour market and encouraging them to join a union;

6. Digitalization, automation and robotization as an opportunity (for example, digitalization, properly controlled, can help to improve working conditions) and a challenge; there are many issues here that are not regulated by national law (for example, working through digital platforms). 
7. The need to regulate platform work - extension of employee rights to platform workers.

8. Technological unemployment.

9. Competency gap - imbalance between the skills of employees and the needs and requirements of employers; it is particularly important in the context of rapidly changing expectations resulting from technological progress.

10. The need to develop protective mechanisms to reduce the outflow of young and welleducated workers from Poland to other EU countries.

In-depth interviews with trade union representatives cast a different light on the three issues in focus: representativeness of social partners, their autonomy and digitalization.

\subsection{Strengthening the Representativeness of Social Partners and Increasing their Institutional Capacity to Shape the Labour Market through Social Dialogue and Consultative Processes}

The reasons behind low membership of trade unions and its constant decline are complex. They can be explained by a number of factors, both external and internal to the labour movement. Considering the former, they include several broader social and economic processes. One social process mentioned by trade union representatives was an increasing focus on individualism, on the one hand, and a progressively smaller role of collective values on the other: 'That's the heritage of the 1990s, of this liberal vision of the economy that was implemented here at the time. Trade unions were viewed as some kind of a burden, a problem for the restructuring of the economy and its proper functioning' (TU).

Reducing the role of collective values in everyday life in favour of the individual is one reason for the decline in trade union density. Another reason is changes in the labour market, which can be seen as the result of globalization and technological change. According to trade union activists, the direction of these changes is evident: the growing scale of fixed-term contracts, the need to retrain, sometimes more than once, in the course of professional career, and frequent change of employers. The labour market in Poland is also becoming increasingly diverse.

The scene was dominated by large industrial plants; people who worked there shared similar views, similar biographies; they were often all males - that was the golden era of trade unions; building a sense of community around them was easier. In a situation where the labour market is more flexible and hence more diverse, where people have different interests, building a sense of group solidarity among them is really difficult. (TU)

The reasons for low representativeness also include factors within the trade union movement itself and are the same in different countries: the problem with recruiting young people and people working in the service sector (which employs two-thirds of the entire working population in Poland), ${ }^{11}$ and problems with recruiting women and foreign workers (in Poland, mainly Ukrainians).

In addition to the changes that must take place in trade unions themselves, increasing their representativeness also requires creating a friendly environment for establishing trade unions, including the media atmosphere and education system (introducing 
elements concerning the labour market or trade unions to the curriculum). 'The media discourse has improved a bit. There are journalists who understand trade unions. They might not be enthusiastic, but at least they don't do harm. I would expect some institutional support from the state' (TU).

You can strengthen employee participation or employee democracy - act indirectly. Let's forget about workers' councils, because they probably died a natural death. We might think about introducing employee representatives to the boards of private companies (although I know its complete science fiction). This would strengthen the position of employees. There is also the issue of creating a good climate. (TU)

When it comes to methods of recruitment, this work is still done mainly in the traditional way, at the grassroots level - trade union activists encourage workers to join by talking to them during cigarette breaks or at local shops where they go to get their breakfast, or by handing out leaflets at the door of their workplaces.

These methods are effective, but they are effective in the manufacturing sector, where there are many people working in one place. They aren't effective in all cases. For example, we've been completely unable to organize international transport drivers, simply because it's more expensive; you need to stand in car parks. The level of their organization is practically none at all. (TU)

The final group of factors tends to be overlooked by labour relations researchers. Also, sometimes crucial from the point of view of trade unions, is the issue of financial resources. The funds that they have at their disposal are very limited:

If we calculate, it turns out that we are more effective if we recruit classic unionists employed in large industrial plants - men. Of course, we are aware that it would be best to recruit Ukrainians driving for Uber, or people doing platform work - but let's be realistic: it's just impossible. The amount of money that would have to be spent on this is huge, and trade unions have limited resources. That's why the resources we have must be used in a classic and rational way - where it's easier to recruit. (TU)

Why do employees not want to belong to the trade union movement? First, this results from the individualism mentioned previously. The conviction that everyone is master of their own destiny and that individual action is superior to collective is instilled in workers from the very moment they enter the labour market. Secondly, they do not want to join a trade union unless something dramatic happens that cannot be resolved in any other way:

People usually organize themselves only when they have a sense of fundamental injustice about their working conditions or about their work as such; for example, working time standards are not respected, they don't receive additional overtime pay, or basic employment rules and norms are broken. The second situation is when word gets around about restructuring, collective redundancy or merger. (TU)

Also, workers do not want to join (or establish) unions, especially in private enterprises, as they are afraid of dismissals or problems they might bring on themselves as a consequence of doing so. One solution to these concerns would be if the National Labour Inspectorate (Państwowa Inspekcja Pracy, PIP) became more efficient. 
Trade unions in the private sector are quickly neutralized or destroyed by employers. If the PIP were efficient, they would immediately send an inspection to such companies, identify the problem and impose sanctions, and an efficient labour court would quickly issue an order of reinstatement. This is also an institutional problem - an efficiently operating labour court would reinstate an employee (a dismissed trade unionist) after three months, and not after four years, as it is now. He would be able to survive three months without work. He would know that if he got dismissed for his trade union activity, the labour court would quickly order his reinstatement and he would be able to continue. But if this involves a two-, three- or four-year prospect, no one will risk setting up a trade union. (TU)

In conclusion, it is worth adding that, according to trade union activists, the reason for low representativeness lies also in workers themselves: they say they do not join unions as they are ineffective, and they are ineffective if they do not have enough members. When a union is viewed as ineffective, it fails to attract new members, which amounts to a vicious circle. Other barriers include employers' hostility to trade unions (especially in private enterprises), a lack of awareness and knowledge about them in general, and stereotypes.

\subsection{Supporting the Autonomy of Social Partners}

The key issue in this area is collective labour agreements. Their number keeps falling every year, which is explained by trade union representatives as follows:

From the point of view of the unions, collective agreements are pointless in their current form. They should only apply to union members and not to all employees in a particular enterprise. If they were restricted to members, others would be more inclined to join so that they could benefit from those agreements. (TU)

Collective agreements in Poland may be concluded at two levels: single-employer and multi-employer. Table 11.1 presents the number of registered collective labour agreements and the number of employees covered by the agreements from 1995 to 2018 at single-employer level.

Based on the data from Table 11.1, note that the number of collective agreements (single-employer level) is decreasing, as is the number of employees covered. The reasons for this were listed by the trade union representatives.

In the 1990s, a certain pattern developed of drafting and concluding collective agreements, which still functions today, although both the social and, above all, economic situation have changed significantly. Thanks to this pattern and to the legislation in place, we can still say (and this is an added value) that trade unions represent and act for the benefit of the entire world of work, all employees, and not just for their members. Since they are a representative of all employees, trade unions have the legitimacy to give opinions on legal acts, participate in tripartite dialogue and influence public policies, including the minimum wage and social benefits. If we departed from this pattern, it would perhaps increase their representativeness, as people driven by their personal interest would start joining trade union organizations, but it would also cause them lose their legitimacy and position in social dialogue. For this reason, there is no indication that this would ever change, which may, however, adversely affect the recruitment of new members. Instead of negotiating more collective agreements, trade unions are busy giving their opinion on an immense number of legal acts, which they are obliged to do under the current legislation. 
Table 11.1 Collective labour agreements in Poland, single-employer level, 1995-2018

\begin{tabular}{lcc}
\hline & $\begin{array}{c}\text { Number of registered collective } \\
\text { labour agreements }\end{array}$ & $\begin{array}{c}\text { Number of employees } \\
\text { covered by the agreements }\end{array}$ \\
\hline 1995 & 7343 & - \\
1996 & 1464 & - \\
1997 & 882 & - \\
1998 & 614 & - \\
1999 & 622 & - \\
2000 & 498 & - \\
2001 & 361 & - \\
2002 & 310 & 117653 \\
2003 & 441 & 174600 \\
2004 & 328 & 181000 \\
2005 & 220 & 119604 \\
2006 & 176 & 68000 \\
2007 & 168 & 121500 \\
2008 & 154 & 62800 \\
2009 & 123 & 62500 \\
2010 & 130 & 172000 \\
2011 & 136 & 50000 \\
2012 & 92 & 61000 \\
2013 & 109 & 43800 \\
2014 & 88 & 43500 \\
2015 & 69 & 106552 \\
2016 & 79 & 38227 \\
2017 & 50 & 28230 \\
2018 & 54 & 21067 \\
\hline & &
\end{tabular}

Source: National Labour Inspectorate reports (2016, 2017, 2018).

Another trade union activist commented on the issue of collective agreements as follows:

Why are there so few of them [collective labour agreements]? The way the unions see it, it's because employers don't want to conclude them. Those that materialize could be explained by an awareness that there is such a possibility, but, on the other hand, they could also be explained by concern about preserving social order: there might have been a threat of a collective dispute. Finally, the third option is that they are there already and they simply continue, just like that; they are kind of taken for granted. (TU)

According to trade union representatives, employers also tend to explain their refusal to conclude such agreements (particularly multi-establishment ones) by claiming that the unions involved do not represent an entire sector. Another problem is that collective agreements are very easy to cancel: 'You just submit notice and it's gone' (TU).

What can be done to have more collective agreements? It is apparent that trade unions expect action from the government. This could involve, for example, tax benefits for business entities that have such agreements. Moreover, the Labour Code includes 
provisions that authorize the minister responsible for the labour market to extend multiestablishment agreements to those enterprises which are not party to them; as specified, such a decision can be taken for reasons of important public interest. ${ }^{12}$ Regrettably, this particular article of the Labour Code has never been applied. The question is, why? It seems that the problem lies in the weakness of collective agreements; there is little they can offer employees, so there is not much point extending them at all.

How can the social partners' autonomy be enhanced? Where can they have a say in decisions concerning working conditions and various elements of labour market policy? In the opinion of the informants, there are two principal areas to consider in this respect. The first is meaningful dialogue in the Social Dialogue Council, which is possible even in the existing legal framework. However, there is a key condition:

I think that when it comes to the tripartite dialogue in the Social Dialogue Council the first thing to do is to start treating the social partners seriously. This refers to things like sending draft legislation to the parliament before the consultations in the RDS have been completed, not listening to the opinions of social partners, not considering their opinions, conducting the legislative process round the clock, at night, asap [as soon as possible], even though the issues at stake are fundamental to the labour market. In most cases, this tripartite dialogue is just a façade. Of course, there is a lot to be done here. It would be enough to respect and observe the law, no more and no less. (TU)

Those observations were confirmed by another trade union representative:

The RDS repeats all the mistakes of its predecessor, the Tripartite Commission. It's a bit like a decoration. It's a case of illusory corporatism. We aren't really supposed to negotiate or work out a common position. It's the same all over again: the government party to the commission is a stronger partner. They come there with ready drafts and they say: 'That's our solution and we don't care much what you have to say because it's all been decided and it's going to the parliament any time now'. (TU)

The other key area on which trade unions should focus is collective agreements. Two issues that always surface in this context are a high level of protection offered by the Labour Code, on the one hand, and limited negotiation space, on the other. Most legal experts agree that the Labour Code is so detailed and so comprehensive that there is not much to negotiate. This view is coupled with a conviction that the level of statutory protection is so high that employers cannot afford to offer workers much more. Therefore, it is simply impossible to bargain. However, trade union activists do not entirely agree with this interpretation:

These are just stereotypes. Let's look at the first of them: if we limited the extent of certain provisions of the Labour Code, we would have more negotiating space, which would be a factor enhancing the autonomy of the unions. But negotiating arrangements that which go below the Code in some areas would have a similar effect. (TU)

When it comes to collective agreements, then, the unions say that they are in a difficult position: it is rather difficult to imagine what they could do in real terms to revive them and make them more popular. A successful attempt would require focus not only on their number, but also on quality. Note that the new collective agreements currently being concluded are increasingly weaker, as the number of union members keeps reducing and 
thus pressure on employers is less effective. As a consequence, the added value of those agreements is limited. They often copy provisions of the Labour Code verbatim, perhaps adding an extra sentence at the end, which does not mean much.

A good example of a multi-employer collective agreement is that for State Forests National Forest Holding. It was established in 1998 and is still valid. The company updates the document frequently. In October 2019, the twenty-ninth upgraded protocol came into force. This agreement applies to all employees of the State Forests. It regulates additional rights in detail, on top of what is entailed by the Labour Code. They receive, among other things, bonuses when the company does well financially (s. 32 of the Agreement). In addition, the agreement contains a list of work the performance of which entitles employees to receive preventive meals throughout the year, ${ }^{13}$ as well as the rules on personal hygiene, personal protective equipment, work clothing and footwear, protective vaccinations, washing work clothes, and so on. This multi-employer collective agreement is one of the most long-standing.

\subsection{Trade Unions and Digitalization}

Trade union activists are aware of the impact of digitalization, robotization and automation on the labour market. However, based on the interviews, it can be concluded that, apart from identifying the problem, there is not much their organizations do in relation to those issues. The informants agreed that their activity in this area is insufficient.

They certainly realize how much technological change works against them. The reasons are fairly obvious: technological progress, including artificial intelligence, means fewer jobs, and the process can already be seen. Also, the jobs that are lost are those which require medium-level skills. The impact of technology in relation to job loss is much greater here than in the case of low- or high-skill positions.

But medium-skill jobs are the traditional base of the trade union movement. The trade union movement has never been based on people with a low level of skills or people with high skills. One point is that the erosion of this middle group will contribute to lower social cohesion and even greater income stratification. Another thing is that it throws a spanner in the works when it comes to organization as such. (TU)

The question is how far trade unions, on the one hand, and employers, on the other, are ready for technological changes. As it turns out, there are increasing developments at the level of particular enterprises: 'Shopfloor factory workers can feel the breath of the robots on their necks; in car manufacturing, for example, employers try to improve the skills of their workers; there is multiskilling; it's a self-propelling process. Employers also want this because they realize what is going on' (TU).

The second important problem in the context of the impact of technology on our lives is the right to disconnect. Our lives are increasingly more online than offline. From the individual's point of view, it is necessary to temporarily disconnect from technology because people are increasingly dependent on it. 'Some companies turn off their servers during the night because people checked their emails all the time. This is more and more often noticed and something is being done about it, especially in sales, where the rat race continues' (TU).

When it comes to platform work, there are no discussions or even attempts to negotiate on this matter in Poland. Trade unions do not treat it as a problem or an issue that should 
be addressed. In Poland, according to the informants, this phenomenon is so marginal that no union will focus on platform workers who earn some extra cash after hours.

If we are talking about such platforms such as AMT, it's just impossible. As for Uber, well, perhaps ... It would have to be something like an EU project; I mean the money for this, for getting Uber drivers organized, for trying to do it. Maybe, just maybe, under such a project someone would try to do something to organize those drivers without any guarantee that the whole thing would work out. (TU)

The other trade union representative openly stated that the unions are only just beginning to examine the problem. Currently, they are at the stage of describing rather than solving it:

I think that if all of those platform workers came to trade unions and asked for protection, they would get help. The unions still need to develop some kind of a mechanism for solving this problem at the systemic and institutional levels. For now, they don't have it, but we are aware of the problem and are slowly trying to include it on the agenda. The unions are a little behind, there is no doubt about that. (TU)

In conclusion, the biggest challenges faced by trade unions include the need for the internal promotion of young and women activists, and for the introduction of an age limit for members of the leadership. However, the informants are aware that these changes are highly unlikely; no one wants to challenge the status quo.

In addition, it would definitely help unions if they were able to promote a better media image. In many cases, they set up trade union organizations from scratch, which is not easy to present to a broader public, and thus far has not been done well.

According to the informants, the changes that would strengthen trade unions and social dialogue in Poland include, for example, increasing the role of the Social Dialogue Council. This can be achieved in two ways. First, social partners in the council need to be taken seriously, and the dialogue should be meaningful and genuinely based on existing mechanisms. As it is now, there is a power imbalance between partners in the RDS: the government side is the stronger and imposes solutions on the others. Until the parties to the council develop partnership relations, social dialogue in Poland will not function. Secondly, the council itself can be strengthened by involving experts. This, however, would require more public funding, which makes it difficult.

Only a steady provision of funds could do anything. But it would have to be done in a smart way; the flow would have to be small. Like support for particular actions so as not to throw the baby out with the bathwater. It would be necessary to develop a mechanism, a subsidy algorithm for employee initiatives, for small unions, small movements. (TU)

None of these mechanisms would work without the will of the government to support social dialogue.

In addition, research ${ }^{14}$ was conducted ${ }^{15}$ among Uber drivers in Poland (in the context of their social rights). The results show very clearly that the drivers do not want to be members of trade unions. The main reason may be the nature of the labour market today: flexible, individualized, demanding constant adaptation to a changing situation, variable and based on new technologies. Under the circumstances, people make themselves 'the centre of their own planning and conduct of life' (Beck 1992, p. 90). 
On the basis of this study, it seems that the unionization of platform work is now impossible. The interviewed drivers do not have a sense of common interest and they stress that their work is only temporary. Consequently, collective values, which are at the core of the trade union movement, are beyond their concern. High rotation and dispersion are additional factors that discourage unions from trying to promote the organization of platform workers.

\section{MAIN CHALLENGES IN THE NEW WORLD OF WORK FACED BY EMPLOYERS' ORGANIZATIONS}

The principal challenges identified by employers' organizations most often include the following:

- the need for changes in regulations concerning the employment of foreign nationals in Poland - in order to maintain the pace of economic development, by 2050 we will need at least 5 million economic migrants, ${ }^{16}$

- the need to extend the simplified employment procedure to citizens of such countries as India, Bangladesh or Pakistan (owing to the outflow of Ukrainian workers to Germany);

- the problem of mismatching between the skills of employees and those required by employers; and

- the need to introduce regulations on temporary work agencies.

In-depth interviews with representatives of employers' organizations cast a different light on the three issues in focus: the representativeness and autonomy of the social partners, and digitalization.

\subsection{Strengthening the Representativeness of Social Partners and Increasing their Institutional Capacity to Shape the Labour Market through Social Dialogue and Consultative Processes}

It turns out that the employers' organizations have a different approach to increasing their representativeness compared with the trade unions. The issue of increasing membership is not their priority and they do not want to recruit new members by resorting to compulsory measures. They expect that the initiative to join should come from businesses themselves: 'We want employers to become associated of their own initiative. We don't support the idea of compulsory associations as such. And so we are not in favour of legal regulations that would make it obligatory for employers to associate' (EO).

The informants noted two main reasons for the low rate of membership of employers' organizations. First, there is no such tradition and businesses do not see the need; they have little awareness of these organizations. The second reason is "the structure of the business sector in Poland: it is dominated by small and medium enterprises. It's difficult for employers' organizations to construct an offer for them. ... this means delegating employees to deal with that, which is practically impossible in small enterprises' (EO). 
Strengthening the social partners is certainly important but it should be addressed at the national level and involve a policy that would encourage membership of employers' organizations; boosting the entrepreneurial spirit, and convincing employers that it is important for them. Activities aimed at increasing representativeness should thus focus on enhancing social dialogue in general, which will translate into strengthening the representativeness of employers' organizations. They also acknowledge the following:

We also face the challenge of how to reach new members. We often hear very blunt answers, like: 'Why would we join; what's the use of all that if there is a principal decision-maker at the top who doesn't listen to partners?'. Entrepreneurs don't see any point in joining organizations. The way we see it, this stems from a general crisis of social dialogue in Poland at the moment. It isn't only about employers' organizations or only trade unions. On the other hand, there still is no message to the public, no idea of partnership, no style of management that would consider joining employers' organizations important. (EO)

Particular initiatives encouraging employers were characterized as follows:

They are mostly promotional activities. Let's not hide that we make a living from the contributions of our members, so this marketing activity aiming to attract new members dominates. But it isn't easy. We encourage them to join, we stress our regional activities. Regional organizations that are affiliated with us operate according to the specificities of the local market. We have our activities as the headquarters, and those regional organizations have theirs. But the main thing is to get as many members as possible. And to represent their interests. (EO)

This indicates that the development of regional structures and activity at the regional level are most effective and desirable: 'It turns out that the issues that employers come to us with are often local' (EO).

It follows that activities should be conducted at two levels: the national level, where there are mainly legislative issues, and the regional level, where issues are local in nature. As regards desirable solutions, representatives of employers' organizations agree with trade unions that the most urgent issue is 'The general strengthening of dialogue, respecting its functions, restoring its status and using it for the purposes for which it was established under the Constitution. This will have an impact on the functioning of employers' organizations and strengthen their representativeness' (EO).

On the other hand, it is also important to build up an accurate image of employers:

The point is to show that, after all, employers create jobs - with their own money, at their own risk, by their own efforts. We don't want an image of employers that's worse than reality, at least. Employers are a group of people who risk their own money, devote their own time and work to build companies and create jobs. (EO)

This issue is related to access to public media:

The opportunity to present employers' organizations in public media is supposedly guaranteed in the Act on Radio and Television Broadcasting (Article 23), which states that employers' organizations and trade unions have the same right to present their views in state media outlets as political parties. We can see what it's like in reality. We have political parties on TV all day long. (EO)

The purpose would be to show the public (including business people) that there are employers' organizations and that they have a mission that they actively pursue. One 
barrier to the expansion of membership is a lack of knowledge about them among business people, who are unaware of what they could do for them.

In summary, although employers' organizations are aware of the need to strengthen their representativeness, they have still not resolved to do it.

\subsection{Supporting Social Partner Autonomy}

In the opinion of employers' organizations, social partner autonomy is directly related to national social dialogue:

This issue is very much related to the crisis of dialogue. Supporting social partner autonomy will make sense if their voice is respected - we respect what you think, we give you a voice - and if it isn't like that now, when public consultations, for example in the Social Dialogue Council, look like an illusory privilege: we can say something, say what we think, but it's a mere formality. If social partners have three days for consultation of a draft legal act - it's just not serious at all. And that's what it looks like now. (EO)

One reason behind the small number of collective agreements is the construction of the Labour Code; it is so detailed that employees often do not see the need to expand their rights. According to employers, such an expansion would not only go too far but also amount to a burden they would not be able to deal with. One representative observed:

This may be partly true. Still, in our opinion it isn't the only problem. The first problem is that some employers are not able to strengthen employee rights for various reasons; but on the other hand the problem lies in dialogue. Even if there is a will on the part of the employer to increase these rights, sometimes it's difficult to agree on how to set about this. (EO)

Employers' organizations also stress that there is a contradiction between how employers and employees approach the provisions of the Labour Code:

Employers talk about the need to make the Code less restrictive, about greater flexibility; they think that they should be allowed to adjust the level of employment to their needs to a greater extent. On the other hand, trade unions say that the Code should be even more detailed and stress employers' obligations and employee rights on some points even more. (EO)

Collective bargaining is not a dominant topic in Poland. There are no agreements that cover entire sectors, and their low number at the enterprise level results from the structure of the country's business sector, which is a domain of large workplaces and enterprises with strong trade unions. One informant observed: 'As a rule, it is an employer and not an employers' organization that is party to a collective agreement in Poland' (EO).

Another representative of employers' organizations noted: 'If we negotiate a collective agreement, it may contain provisions that are more favourable to employees and thus less favourable to the employer, and not the other way round. And this is one of the barriers' (EO).

What solutions do employer organizations propose? One option is to amend the Labour Code:

We could make a package deal: we, as employees, agree to this, and in return we get that. With this logic in place there would be more collective agreements because some options would 
be open - options that ... employees agree to some changes that are more favourable to the employer and vice versa; in return they would get other things that are important to them. With this approach there would be agreements. This would require deviations from the Labour Code; they wouldn't apply to all employees but only some of them. What I mean here is particular sectors. In this case, a provision that is beneficial in one sector will be a problem in another. There could be an additional safety mechanism that would condition such deviations from the Labour Code on approval by trade unions or - in workplaces which don't have them - by employees. (EO)

In summary, it should be observed that although employers' organizations have full autonomy to make their own decisions, their influence on shaping collective labour agreements is negligible. This stems from a number of factors. First, they are not parties to these agreements at any level. Second, the vast majority of collective agreements in Poland are concluded at the enterprise level, and one of the parties involved is a particular employer, not an organization. Third, the number of multi-establishment agreements (those to which an employers' organization may be party) is very small and falling (at the end of July 2019, there were 87 binding agreements of this type - out of the 174 in the register - covering only 200000 employees). ${ }^{17}$ Fourth, low trade union density, on one hand, and the structure of the business sector in Poland (dominated by small and medium-sized enterprises, SMEs), on the other, are not conducive to increasing the number of collective agreements. Fifth, according to the Labour Code and other legislation, collective agreements may only contain provisions which are more favourable to employees than are their statutory rights. Many employers are convinced that these regulations provide so much protection to workers that they do not want, or cannot afford, to offer them more.

\subsection{Social Partners and Digitalization}

Employers' organizations are aware of new trends in the world of work stemming from technological changes. Similar to the trade unions, however, they do not yet fully know how to deal with them.

Work culture and the way work is done is changing. We have digitalization and other processes and, as employers, we face the challenge of how to manage this new form of work. We have fewer and fewer employees; a large number of companies have to invest in automation and robotization. On one hand, we introduce automation because we don't really have much choice - there are no people willing to work. On the other hand, these processes also generate new jobs. (EO)

Also, employers believe that digitalization and robotization are such serious issues in the context of the future of work, that approaches to dealing with their challenges should be developed through social dialogue:

A robot may not have needs like an employee; but we also see the need for social security for employees who are here and are really valuable. Because there are fewer and fewer employees, we think they should be even more appreciated. There will still be jobs where machines cannot replace people. But you also need to support the process of automation because companies have to grow. We have to listen to each other; it all needs to be balanced. The role of social partners is very important: they have to react to these changes, taking their needs into account. (EO) 
Another informant emphasized the following:

As an employers' organization, we can see this digital transformation, we can see that it's changing employment relations in some ways; for example, we have something like teleworking, which isn't really regulated by the Labour Code, or platform work, where even the employment relationship is somehow lost. (EO)

On the one hand, then, employers' organizations are aware of the changes that are taking place in the labour market, which result from technological progress; on the other, they do not treat them as a problem that must be tackled today. They tend to see them as a chance for development rather than a threat. They are also aware that the law in Poland cannot keep up with technological progress. Talking about this, one of their representatives stressed that 'As employers' organizations, we have nothing to do with platform work - none of our members is involved in this kind of activity' (EO).

\section{CASE STUDIES}

\subsection{Case Study 1. The Sworn Translators ${ }^{918}$ Trade Union: Example of a Trade Union with Freelancers as Members}

\section{Introduction}

Established in 2017, the members of the Sworn Translators' Trade Union in Poland (Związek Zawodowy Tłumaczy Przysięgłych w Polsce, ZZTP) do not work in one workplace, but are dispersed throughout the country. Most of them are self-employed, which means that their professional situation is more insecure. The ZZTP is an example of a trade union that deviates from how we have imagined these organizations thus far.

We must remember that the labour market in Poland is diverse. Industrial sectors (such as mining or the car industry) have a rich trade union tradition and trade union membership is common. However, in service sectors dominated by freelancers, trade unions practically do not exist; therefore, employees usually do not have any protection against employers' abuses of their rights.

The ZZTP is one of the few exceptions here, and for this reason is particularly worth analysing. It also perfectly illustrates current developments on the labour market: flexibility of employment and self-employment, on the one hand, and increasingly limited job security (especially in economic terms) and uncertainty, on the other. Sworn (or certified) translators often work remotely, online; they may be worried about their future owing to the progress of advanced automation and digitalization processes that may lead to their replacement by software. The work they do reflects the trends that we have long seen on the Polish labour market; that is, flexibility of work, characterized by high uncertainty and instability, and progressive automation and digitalization, which may threaten the existence of some professions in the future.

\section{Incentives to establish a trade union}

Like any professional group, sworn translators have their problems. The main motives for establishing the union included the need to resolve issues that they faced on a daily basis in cooperation with the judicial authorities, mainly concerning the improvement of 
working conditions and pay. For example, the rates for certified translations, which are subject to official regulations, have not been increased for 14 years. ${ }^{19}$ The ZZTP operates on the basis of the Trade Unions Act on and thus can conduct talks with the Ministry of Justice (which is an employer of sworn translators).

The ZZTP's mission is to protect the rights and interests of sworn translators, in particular: to optimize their working conditions, to support members in disputes with judicial and public administrations and in their work, to increase the rates of pay for sworn translators, to strive to adapt the Act on the Profession of Sworn Translators to current conditions, to develop uniform working standards for sworn translators, to consolidate and integrate members of the profession, and to strengthen its image as a profession of public trust.

\section{Outcomes: a mixed situation}

On the basis of an in-depth interview with a representative of the union, it can be concluded that not many of these aims have been achieved so far. When talking about the reasons for failure, he mentioned, above all, difficulties in recruiting new members:

I'm aware that the strength of an organization also lies in the number of its members, and we have a problem with that. I mean, people don't want to join unions, and it isn't only our problem. I think there are at least two reasons for this. The first is that unions have bad connotations: they are associated with elderly men in sweaters who are busy acting as union activists; all the benefits they manage to achieve apply only to themselves. There is this conviction that if someone works in a union, he works only for his own good and it has no impact on the people he represents. The second reason is the strong politicization of trade unions so far, especially union centres, and especially people in top positions. In Poland, we have two main trade unions that are clearly associated with particular political parties. The successive leaders of those unions have confirmed this more or less openly. This means that in the media discourse we have this image of competition between them, and not of their joint defence of the rights of employees. (ZZTP)

This comment also indicates the two main reasons why trade union density in Poland is so low. These issues were not mentioned by representatives of other trade unions. The first reason is a negative image of trade unions among the general public. This is also confirmed by a survey conducted by the Public Opinion Research Centre (CBOS) in 2017, ${ }^{20}$ which shows that the majority of Poles (41 per cent) believe that unions are ineffective, both when it comes to their activity for employees in workplaces and, more broadly, for the defence of employees' interests in Poland. The second reason is the politicization of the largest unions. History has shown that many of their leaders or people in high office treated their functions as a springboard for national politics.

The interviewed ZZTP representative, however, stressed that that the founders of the union wanted to create a modern, effective and, above all, non-political organization:

Our union is completely different. None of us has any trade union experience and we haven't followed any existing organizations. None of us has any political ambitions either. We wanted to create a modern organization which would be the voice of the whole community of sworn translators. But unfortunately, we can't overcome people's mentality. We're unable to overcome this overall negative image of trade unions. People don't want to join us because they don't believe we're going to be effective. And we won't be effective if we don't have the entire community behind us; it's a vicious circle. (ZZTP) 
This comment shows that, despite its very modern approach, attempts to detoxify the current image of trade unions have failed. The translators' union has not been very successful: it has not achieved its basic aim - to raise the official regulated rates for certified translations - despite numerous attempts to influence and negotiate with the Ministry of Justice.

However, despite the limited possibilities of action resulting from the wide geographical dispersion of the members, they managed to achieve (at least in part) what the trade union has sought from the beginning. They managed to win higher pay rates for sworn translators, which came into force at the end of 2019. The way the trade union operates, the strong emphasis on the development of regional structures, frequent meetings in larger cities and the organization of additional training and workshops, have undoubtedly contributed to this success. Thanks to this increased activity, they have managed to unite the members and jointly fight for higher rates.

\section{Challenges for the future}

In the context of strengthening trade union representativeness, the first task is to try to change their image. The unions themselves should evolve into more modern organizations (perhaps resembling corporations) and show that they work for people and not for themselves. However, the public needs to be shown how they work and that all those who engage in union activities have a task; if you sign up to a union, you should be active and not just be a name on a list. Owing to the small numbers, not just some but all members must be active. For this reason, the union has found it difficult to recruit more members (but all trade unions have problems with this). However, as the interlocutor stressed several times, nothing can be done without changing the image of trade unions and this is the most difficult task.

The example of the Sworn Translators' Trade Union in Poland is important for several reasons. First, it shows that it is possible to act even if employees are geographically dispersed and do not have a common employer (in the traditional meaning), although they do have common problems. Secondly, it is one of the first initiatives that connects people who are self-employed (freelancers). Thirdly, it can be an example for all employees who work on the basis of civil law contracts or are self-employed that the lack of an employment contract is no longer a barrier to creating and acting in a trade union. The modest, though significant successes of the union prove that it is worth making the effort to try to improve the situation, even if there is no strong and large trade union organization in the background.

\section{Conclusion}

The Sworn Translators' Trade Union in Poland is one of the few trade unions that represents the self-employed (freelancers). It is a good example for other self-employed occupations that are not yet unionized. Together they were able to improve the financial situation of all sworn translators (the trade union contributed to the introduction of higher pay rates for sworn translators).

\subsection{Case Study 2: Company $A$ in e-Services}

\section{Introduction}

In 2018, LinkedIn Top Companies listed Company A as the company for which American professionals most want to work. That is why the operations of Company A 
in the e-services sector attract great interest around the world, including in Poland. The company opened its first two distribution centres there in October 2014. At the end of 2017, new centres were launched and another was opened in 2019. Along with the one that is scheduled to become operational in 2020, the company now has six distribution centres in Poland.

Initially, Company A appeared to be an ideal employer in Poland: it was considered a prestigious, 'Western' company offering stable jobs. It soon turned out, however, that opinions about it are strongly divided; from enthusiastic (based on the fascination with technology and innovation, and global economic success) to extremely negative, dominated by the criticism of high performance norms and dehumanised treatment of employees, reduced to mere algorithms. This has also stirred concern that its global business model is applied here at the expense of employees' rights, and that the ongoing expansion is a result of the hard work of thousands of workers rather than innovation. The question asked by researchers is whether Company A, and other Western global players investing in Poland, take advantage of lower labour costs, a well-qualified workforce and flexible labour law without providing adequate employee security as offered in many Western economies (Owczarek and Chełstowska 2016, p. 6).

Alternatively, as one of Company A's managers said, 'the Company's aim is to provide the best service to the client, and this desire is the driving force of innovation and development. But this would not be possible without accepting failures, which are part of experimenting, are part of the nature of introducing the latest solutions'.

\section{The presence of trade unions}

In December 2014 (less than two months after the opening of the first centre) the first trade union was established in Company A: the Workers' Initiative at Company A (hereafter Workers' Initiative), affiliated with the All-Poland Trade Union Workers' Initiative; another trade union, affiliated with Solidarity, was registered in January 2015. The establishment of both was motivated by the well-being of employees in general, and the intention to represent their interests in dealing with the global employer in particular.

The impulse came from several employees, the lowest in the hierarchy, who attended training courses at Company A in Germany and Britain. When they returned to Poland they were unhappy about the differences between the working conditions in Poland and in those other countries. From the beginning, the initiators of Workers' Initiative were convinced that Poles were treated worse. However, we soon noticed that the company was starting to apply pressure as regards the pace of work, but the earnings were not satisfactory; and so we decided to establish a trade union (Workers' Initiative).

Initially membership was only 12 or so people among several thousand workers, but now (October 2019) the union has a membership of over seven hundred. Considering that the number of all Company A employees in the country is between 14000 and 16 000 , this proportion is not particularly impressive. However, the problem here is the structure of the corporation in Poland: there are six centres in different parts of the country. While some of them (especially those recently opened) have no unions at all, trade union density in others is high for Polish conditions (and the industry). Workers' Initiative in the centre near Poznań has about 500 members out of 3000 employees, just under 17 per cent. 


\section{Working conditions in Company A}

The numbers in employment, and thus trade union membership, change dynamically owing to the substantial rotation and turnover of employees in the company. Also, only a quarter have indefinite contracts; all others have temporary contracts with Company A or are employed by temporary work agencies. According to a union representative, this situation stems from the economic model adopted in Poland (Workers' Initiative). He explained:

We keep struggling with structural problems - for example, constant rotation and turnover in the company. On one hand, employees who have worked here for a long time change jobs, on the other - new ones have to go through the ordeal of agency employment first (nine months on monthly contracts, for example), then they work on a three-month trial contract and then on a one-year contract, which of course can also be terminated without consulting trade unions. It turns out that you can count on a better contract only after two and a half years. Very few employees survive long enough to see it: if you get sick during this period or you don't fulfil performance norms, you don't get the next contract. And so these people are afraid to join the union. We would have three times as many members if we counted everyone who went through our ranks. It's because of this huge turnover and this instability that we are struggling with these problems. In these circumstances, we consider these 700 people a great success. (Workers' Initiative)

The company operates within the law. It does not dismiss trade unionists, but does not undertake any communication with them either; it recognizes the body known as the employee forum as the only partner for discussion. The problem is that this body is composed of people who are practically selected by the company itself, and has no rights to conclude agreements on behalf of all the workers.

Company A's trade union members stress the following:

This dialogue is just a façade and nothing more. I'd even say there is no dialogue at all. Company A isn't interested and negotiates only when it's forced to do it under the law; and Polish law is very weak. Several issues that should be regulated in a collective agreement are not consulted with us [trade unions] at all. (Workers' Initiative)

Company A's representatives stress, however, that the company will never discriminate against employees based on gender or age. Each employee is medically examined before starting work, to assess whether their age and health status allow them to work in a specific position. The job description and list of harmful factors are available to the occupational medicine doctor. Therefore, it is the doctor and not Company A who assesses whether the age or health of the employee allows them to work there. ${ }^{21}$

\section{Negotiations on the performance assessment system}

It seems that 2019 brought a breakthrough, however. It all began in September 2018, when a seemingly straightforward matter led to a conflict. One of the few matters that Company A has to negotiate with trade unions is the amount of the Christmas bonus. The unionists decided to use this opportunity to raise the most pressing issue, the employee performance assessment system, which they considered unfair: a worker who fell below 100 per cent of the performance norm (even AT 99.9 per cent) received negative weekly feedback, which could provide the basis for their dismissal at some stage. The unions agreed to the amount of Christmas bonus, which was not 
very high, on condition that the employee performance assessment system would be suspended:

Company A was up against a wall a bit. They signed an agreement. It was a breakthrough for us because the assessment performance system, along with pay and contracts for an indefinite period, is the biggest problem in our company. Employees were not rated for productivity for five months, from September to February 2019. During this time, we had seven meetings with the management. We didn't reach an agreement about the assessment system because all our proposals were rejected, and in March the employer brought the old system back. (Workers' Initiative)

When the employee performance assessment system was restored, performance norms were increased. All employees felt they were under great pressure; they also strongly resented the pace of work, which, in their opinion, became unbearable. As a consequence, both unions operating at Company A (Workers' Initiative and Solidarity) initiated a collective dispute in which they demanded: (1) a decent pay rise (25 złoty [circa $€ 6$ ] after tax); (2) a new employee assessment system (without the feedback); and (3) stable working conditions: contracts for an indefinite period. ${ }^{22}$ The unions stressed that the assessment system was unfair as it did not take into account achievements: decisions on dismissal were made only on the basis of the number of negative assessments generated by the system. The parties to negotiations did not reach agreement and signed a record of divergence.

The next stage of the dispute involved negotiations with the participation of an independent mediator, which were broken by Company A:

It was really bizarre. There were three demands on the table, including a pay rise. We were to meet to negotiate the amount. The meeting was to take place at $10 \mathrm{am}$, and at 7 am all employees in Poland got a text message that they would receive a pay rise in July. It wasn't as much as we [the unions] wanted. But this also shows their logic. The mediator was shocked by the situation what kind of social dialogue is that if the employer resorts to a fait accompli three hours before a meeting with the mediator and the trade unions? Company A claimed they had offered the pay rise themselves; they also said they were not ready to meet the other two demands anyway, so they broke off the negotiations. (Workers' Initiative)

In accordance with procedure, both trade unions at Company A moved on to the next stage of the dispute, a strike referendum, which has still not been concluded: 'We don't know when the referendum will be over because we keep struggling with structural problems. We don't have easy access to employees because we work shifts. People commute from different places, so the votes are flowing in quite slowly' (Workers' Initiative).

When it comes to this area, Polish law is very general and the Act on the Settlement of Collective Labour Disputes (1991) ${ }^{23}$ is inadequate in the current circumstances. A union representative explains: 'We are trying to get the votes via the internet, but we already know that the employer will want to challenge this method in court. For now, we are striving to get over 50 per cent of the employees. ${ }^{24}$ We are over 30 per cent now' (Workers' Initiative).

The problem is that there is one employer, Company A, which employs people in six centres around the country. A strike must be supported by the majority vote of more than 50 per cent of all employees (about 7500). 
However, apart from the demands addressed to the employer, the action conducted by the unions is also indirectly addressed to the public, and in particular to the authorities that are responsible for legislation:

Our goal is to articulate employees' dissatisfaction with working conditions. But we also want to show that the Act on Collective Disputes includes provisions that are quite absurd. In our case, the right to strike is only on paper; it's impossible in a company with such a structure as ours. Another thing is to draw attention to the fact that the law is inadequate in the current conditions. (Workers' Initiative)

The company stresses that they have created over 14000 permanent, good jobs in Poland. They provide employees with a competitive wage and among the best benefits and opportunities for occupational development in the industry. ${ }^{25}$

There are also other issues, such as drawing attention to the insufficient powers of the National Labour Inspectorate (PIP) but the key problem is the pace of work:

We tried to measure energy expenditure at work because we thought Company A's estimates were too low. We invited an independent company to investigate this and it turned out that the energy expenditure required to fulfil performance norms was several times over the limit. Company A challenged these results and the court ruled that energy expenditure is not the same as effort. (Workers' Initiative)

From the employers' viewpoint the question of requirements looks a little different. They admit that there are requirements, but they are not laid down in advance. The company takes the results achieved by employees responsible for a given process in each centre over a period of four weeks, and they become targets for the next four weeks. This means that there are periods in which goals are higher, as well as periods in which they fall to lower levels. If anyone has a problem with achieving the set goal, the company offers them free dedicated training. The company admit that they would have to close the business if they imposed goals (on the current labour market) that they were unable to achieve. $^{26}$

Another problem is the Labour Court. One union member was dismissed on the grounds of non-compliance with performance norms. He took it to court and won his case in the first instance; Company A appealed and the case continues. The court also showed a lack of understanding of the situation: it awarded an employee who had been dismissed unlawfully three monthly wages; the case has been going on for three years and there is still no final and binding judgment. This shows the weakness of Polish labour law.

The above example shows what social dialogue (or a lack of it) looks like at enterprise level. Company A is certainly stronger and rejects union proposals to improve working conditions. However, trade unions operating within particular distribution centres are not discouraged by the situation. It can even be said that the employer's stubborn attitude has united the different organizations, which have had disagreements about their approach.

Also, the company recruits people from areas with high unemployment and a low level of vacancies. Company A offers them transport from home to work and back (which in extreme cases can take up to two hours each way), and thus binds them to the company. There are hardly any people from the area working in the distribution centre near 
Poznań: they are mostly commuters from all over the Wielkopolska region; the pattern is the same in the other centres. They depend on Company A because they have no alternative job opportunities in the area where they live: 'An employee like that says: I don't like it, but I'm afraid of losing this job because I won't find anything else. I have a permanent contract here; I have a loan to pay off and I have to work here. I have no alternative' (Workers' Initiative).

The example of the Company $\mathrm{A}$ in the e-services sector is important for several reasons. First, it shows that it is possible to defend employees' rights even in a big private company. However, it shows that this is not easy and that the employer is in a stronger position. The trade union activity in the Company A proves that the existing law (Trade Union Act) is difficult to adapt to new business models in Poland. For example the existing law allows strike action, but also lays down requirements that are impossible for trade unions to achieve in a firm such as Company A. This might need to be solved within the RDS. Company A aims to find innovative solutions. Some innovations are easily adaptable, but some are not.

\section{Conclusion}

Company A illustrates well the Polish labour market's problems. First, there are many foreign companies (such as Company A) that are located in Poland mainly owing to lower labour costs (compared with other EU countries) and highly qualified employees. Secondly, the business model that Company A has introduced in Poland, in common with many other business models from the Western hemisphere, does not always work in post-communist countries. Thirdly, the problems that Company A has to face in Poland are the same as those in the whole e-commerce sector.

That is why the trade unions face numerous difficulties within the new types of e-commerce companies. The first is related to the different geographical locations of these companies' headquarters, the second is the high staff turnover typical of this sector and the third is employees' general reluctance to join a trade union. The trade unions in Company A indicate that the employees' problems are the same in every company in this sector and there is a constant struggle to protect their rights.

However, we need to remember that the problems emerging within the e-commerce sector are similar in many countries, and to some extent related to the business reality which is changing faster than the law. Companies and trade unions both have to act within a legal framework that is not sufficiently adapted to e-commerce.

The only way to overcome these problems is to enhance the capacity of the social partners and social dialogue in this sector. Within the social dialogue (in this example, RDS) new regulations that are important in the e-commerce sector might be discussed, taking into account the problems faced by trade unions and employers. Trade unions from Company A drew attention to the inadequate strike laws that are impossible to apply in this sector. 


\section{THE VOICE OF THE CENTRAL PUBLIC ADMINISTRATION: THE MINISTRY OF THE FAMILY, LABOUR AND SOCIAL POLICY, DEPARTMENT OF SOCIAL DIALOGUE AND SOCIAL PARTNERSHIP ${ }^{27}$}

\subsection{Strengthening the Representativeness of Social Partners and Increasing their Institutional Capacity to Shape the Labour Market Through Social Dialogue and Consultative Processes}

The Act on the Social Dialogue Council and Other Institutions of Social Dialogue specifies the representativeness criteria for social partner organizations. Those that fulfil the criteria are entitled to participate in the work of a number of social dialogue bodies, including the Social Dialogue Council, Regional Social Dialogue Councils and newly established Tripartite Sectoral Working Groups. In addition, a number of ministries have bodies and teams appointed as experts and advisers, one of which is the Labour Market Council at the Ministry of the Family, Labour and Social Policy. Although these forums serve different purposes, they provide additional opportunities to articulate social partners' expectations.

Labour market issues are within the scope of interest and activity of most social dialogue institutions. They are discussed both at plenary sessions and in working groups dealing with particular topics.

The Act on the Social Dialogue Council granted the social partners a number of new prerogatives, which strengthened their role in dialogue with the government in this forum. Most importantly, the Act granted them not only the right to express opinions on draft legal acts, but also they can prepare their own draft guidelines, draft bills or other draft legal acts. They can also conduct a public hearing, file joint applications to issue or amend legislation or any other legal act concerning issues within the competence of the Council, and the chair of the Council may apply to the Supreme Court for a ruling on a point of law.

The Act on the Social Dialogue Council which is currently in force provides a legal framework and a number of instruments that enable the social partners to affect the socio-economic environment, including the labour market.

\subsection{Supporting Social Partner Autonomy}

There are a number of reasons why there are few collective agreements. They include decreasing trade union density, low membership of employers' organizations and the reluctance of employers to incur additional labour costs in conditions of relatively high statutory standards. Another significant barrier to concluding collective agreements is the considerable variation in the economic situations of particular employers. Most important, however, is the economic environment in which they operate. Fierce competition and constantly changing trends and consumer tastes not only affect the demand for goods and services, but also require a capacity to invest in modern means of production and to dynamically change the field of operations. Consequently, we have long observed an increasing demand for more flexible methods of setting pay at the level of the workplace. This trend contradicts the established European model of negotiations at a level 
higher than that of the individual employer. It should be remembered, however, that this model was developed in the stable European market economies, before the opening up of labour markets to the free movement of people, services and capital.

The severe impact of the 2008 financial and economic crisis on collective labour agreements is also a factor. This led to significant changes in the structure of employment relations and working conditions in EU member states. Processes set in motion at the time brought about the progressive decentralization of collective bargaining.

In Poland, the trend of decentralization in wage determination emerged much earlier than in other EU countries. After the political transformation of 1989, the functioning of business entities changed completely, which led to a significant weakening of sectoral negotiations and, practically, their demise in the following years. The new model of collective labour relations introduced during this period could not foresee the dynamic progress of restructuring processes in many sectors and workplaces. The Polish economy is no longer dominated by giant workplaces but by micro-entrepreneurs and small enterprises. The Polish SME sector is characterized by a negligible level of membership in employers' organizations, on the one hand, and trade union density close to zero on the other; it is slightly higher only in the public sector. Poland belongs to a group of countries characterized by a low level of unionization, at 12 per cent. It was three times as high in the early 1990s.

These factors have an impact on the implementation of the current provision of the Labour Code according to which the conditions of pay are determined in collective agreements and, in their absence, in remuneration rules (Article 77.1). The application of these agreements in practice has clearly been in decline for several years. Before 1995, the year that saw the introduction of a new Labour Code, most workplaces had been party to sectoral collective agreements. Since then, there has been not only a continuous decline in the number of new multi- and single-establishment agreements, but also an increase in the number of those that are cancelled. It should also be noted that neither the Tripartite Commission for Socio-Economic Affairs, nor its successor, the Social Dialogue Council, managed to conclude any multi-establishment collective agreement, even though they have had statutory power to do so. Nor did the social partners take advantage of the possibility of extending the application of multi-establishment agreements to employers who are not party to any such agreement.

Considering the above, it seems that the dominant form of wage determination for Polish employees is an individual employment contract, although in practice a significant number of them are employed on the basis of civil law contracts, which means that they do not have the status of an employee as defined in Article 2 of the Labour Code. However, the few existing collective agreements apply to employees in the public sector or in business entities controlled by the state as the majority shareholder.

In the absence of collective agreements, trade unions are increasingly seeking legislative solutions. However, statutory regulations cannot respond flexibly to dynamic economic changes and social expectations. Although the government supports social dialogue with trade unions and employers' organizations, it should be remembered that in a democratic state the role of the government is to create appropriate legal standards which foster negotiations and agreements. The model of these standards should be decided by its beneficiaries. 


\subsection{Social Partners and Digitalization}

It is estimated that platform work is the main occupational activity of about 2 per cent of the adult EU population, which is relatively small. Work in the sharing economy is often undeclared, that is, performed outside the legal system. Some companies take advantage of the situation and operate according to the principle of privatizing profits and socializing losses.

In Poland, platform work is performed mainly on the basis of self-employment and non-standard forms of employment (mandate contract and contract to perform a specified task). Owners of digital platforms may view the absence of adequate legal regulations as an opportunity to save on employee rights.

Issues related to platform work, which include providing platform workers with the opportunity to benefit from social dialogue, have not yet been sufficiently examined in Poland. The nature of this work requires further study. As concerns social dialogue, the complexity of the phenomenon entails problems in relation to proper representation, especially when it comes to employees. Pursuant to the amendment to the Act on Trade Unions enacted on 5 July 2018, persons performing such work may establish trade unions and join existing ones.

\subsection{How Does the Government Party to the Social Dialogue Council See Its Role as Regards Social Dialogue in the Context of the Future of Work?}

New forms of employment, particularly those related to the digital revolution, may need new regulations at appropriate levels. Expert cooperation and exchange of good practices is recommended in order to select the best way of developing those regulations.

In Poland, the government and the social partners both attach significance to EU cooperation in general, and the European Semester, the European Pillar of Social Rights and the new agenda of the European Commission, in particular. The Social Dialogue Council is an appropriate forum for dialogue in this area.

Cooperation with other international organizations, particularly the International Labour Organization (ILO) and the OECD, is also viewed as important. For example, the work of EU expert groups in the information and consultation of employees indicates that the first measures needed include the development of guidelines and best practice. Experience to date indicates that collective bargaining and employee participation mechanisms at the enterprise level are appropriate tools to respond to changing needs in this area. The knowledge and experience of the social partners can be a valuable contribution to implementation of the EU social acquis.

\section{CONCLUSIONS}

The social partners have different emphases in relation to the problems besetting the Polish labour market (that is, high rate of temporary employment, high proportion of civil-law contracts and labour market shortages). Employers' organizations are particularly interested in recruiting more employees to maintain productivity and development. One solution for labour market shortages may be migrant workers (especially from 
Ukraine, but also from Asia). According to the employers, however, the situation is not so simple. The main problem lies in government administration at the regional level, which is responsible for issuing work permits and legalizing the status of migrants in Poland. The procedures take a very long time and are extremely complex.

Alternatively, the trade unions note that migrant workers often work under worse working conditions than do local workers. This is partly owing to the dishonesty of the intermediaries (work agencies) who organize the work in Poland, but partly owing to their ignorance of Polish law, and sometimes owing to the dishonesty of employers.

Trade unions and employers' organizations should, within the framework of social dialogue, seek solutions that will be attractive to both and that improve the situation of migrant workers in Poland.

Poland has low trade union density and a low membership rate among employers' organizations. It also has a very low level of collective bargaining compared with other European countries. These affect the level and quality of social dialogue in Poland. With such a low trade union membership, on the one hand, and a very detailed and strict Labour Code on the other (limiting the activities of employers), there is no room to establish new collective agreements and shape collective labour relations. This does not mean that there is no such activity, but it is low key. That is why it is worth trying to strengthen social dialogue at the national level as well as at the regional level.

The surveyed social partners unanimously emphasized that the existing formula of the Social Dialogue Council generally works well in conducting social dialogue in Poland, and the only problem, and crucial, is the imbalance of power within the council, with all the advantage going to the government.

Nevertheless, it is worth highlighting those activities of the council that are directed to the future world of work. One of these is Resolution No. 48, adopted by the workers' and employers' sides (within the RDS) in 2017, which concerns recommended changes in the national education system, specifically vocational education. The social partners indicated that reform of the vocational education system should be based on strengthening practical learning at the workplace and closer linking of the direction and content of education to the needs of the labour market. The social partners claim that this change should be prepared in close cooperation with employers' and business organizations, as well as with the trade unions. Discussions on promoting vocational training in Poland in cooperation with employers' and business organizations and trade unions were also the subject of RDS debate in 2018.

Within the RDS there is a working group that focuses on labour law. It was established to develop common positions on issues related to individual and collective labour law. Since December 2016 there has also been a sub-team for labour market policy reform. In 2018, it focused on the employment of foreigners in Poland and Polish labour market needs in relation to hiring migrant workers. In 2018, a debate started which was aimed at developing recommendations for long-term migration policy.

During the meeting in February 2018, the government representatives declared their readiness to talk about the demands of employers, who wanted more flexible employment opportunities for foreigners, and trade unions, who were calling for the maintenance of social standards and safeguards for employee safety.

According to the interviewees, changes that would strengthen trade unions and social dialogue in Poland include enhancing the role of the Social Dialogue Council. This is 
worth emphasizing since the social partners would prefer a more prominent role in the council, even if they are aware of its defects. This may lead to an improvement in the social partners' role in autonomous social dialogue.

Trade union representatives suggested that the role of the RDS may be improved in two ways. First, the social partners in the council need to be taken seriously, and the dialogue should be meaningful and genuinely based on existing mechanisms. Currently, there is a power imbalance between partners in the RDS: the government side is the stronger and imposes its wishes on the others. Secondly, the council itself can be strengthened by bringing in experts.

The employers' organizations voice similar views. They also insist on a general strengthening of dialogue, respecting its functions, restoring its status and using it for the purposes intended by the law. They see a need to enhance the role of social dialogue at national level. They also support stimulating and strengthening social dialogue at lower, regional levels. That is why they pay particular attention to their regional structures and support local activities.

In relation to collective agreements note that, from the employer organizations' point of view, their influence on shaping collective agreements is negligible. This stems from a number of things. First, they are not parties to these agreements, at any level. Secondly, the vast majority of collective agreements in Poland are concluded at the enterprise level. Thirdly, the number of multi-establishment agreements (those to which an employers' organization may be party) is very small and falling. Fourthly, low trade union density, on the one hand, and the structure of the business sector in Poland (dominated by SMEs), on the other, are not conducive to increasing the number of collective agreements.

Given the aforementioned domination of SMEs it is worth asking how to help the social partners to extend their coverage and the number of collective agreements in SMEs. It is worth promoting activities aimed at SMEs and showcasing positive outcomes from SME employees joining trade unions. One option that the social partners may recommend to the government (within the RDS) is to offer tax concessions to SMEs that help their employees to establish a trade union. An increase in the number of trade unions would, in turn, help to boost the number of collective agreements. Only strong cooperation between the social partners and the government will improve social dialogue in Poland.

\section{NOTES}

1. Ustawa z dnia 24 lipca 2015 r. o Radzie Dialogu Społecznego i innych instytucjach dialogu społecznego, Dziennik Ustaw (Journal of Laws) of 2015, item 1240.

2. See http://www.dialog.gov.pl/dialog-krajowy/rada-dialogu-spolecznego/uchwaly-rds/ (accessed 16 September 2019).

3. See http://www.dialog.gov.pl/dialog-krajowy/rada-dialogu-spolecznego/uchwaly-partnerow-spolecznych/ (accessed 16 September 2019).

4. See http://www.dialog.gov.pl/gfx/mpips/userfiles/n.krasuska/RDS\%20i\%20ZESPOLY\%202018/Sprawoz danie.pdf (accessed 16 September 2019).

5. In the report on the activities of the Social Dialogue Council from 2018 one can see that the social partners pointed to irregularities related to consulting draft legal acts submitted to the Council. They argued, among other things, that the consultation dates of legal acts were violated, which prevents the Council from expressing an opinion and that there are still examples of government initiatives following the parliamentary path, which cuts out consultation with the Social Dialogue Council (p. 27 in www.dialog.gov. 
pl/gfx/mpips/userfiles/n.krasuska/RDS i Zespoly 2019/Zalacznik do uchwaly 34.pdf, accessed 11 January 2020).

6. See https://stat.gov.pl/obszary-tematyczne/gospodarka-spoleczna-wolontariat/gospodarka-spoleczna-trz eci-sektor/partnerzy-dialogu-spolecznego-zwiazki-zawodowe-i-organizacje-pracodawcow-wyniki-wstep ne,16,1.html (accessed 24 September 2019).

7. There are currently no data on trade union membership among workers other than those employed on the basis of employment contracts.

8. See http://www.oecd.org/migration/humanitarian-migration-falls-while-labour-and-family-migration-ri ses.htm (26 September 2019).

9. According to the OECD, temporary employment includes wage and salary workers whose job has a pre-established termination date. National definitions broadly conform to this generic definition, but may vary depending on national circumstances (accessed 27 January 2020 at https://data.oecd.org/emp/ temporary-employment.htm).

10. See http://www.opzz.org.pl/assets/opzz/media/files/d2bde577-f1ee-4487-ae30-94714ab2fd99/program-op zZ-na-lata-2018-2022.pdf (accessed 1 July 2019), http://www.solidarnosc.org.pl/images/files/dokumenty/ uchwaly/programowe/Uchwala_Programowa_XXIX_KZD.PDF (accessed 30 June 2019) and http:// fzz.org.pl/wp-content/uploads/2019/04/Praca-na-rzecz-lepszej-przysz $\%$ C5 $\% 820 \%$ C5\%9Bci-executive-su mmary.pdf (accessed 1 July 2019).

11. See https://stat.gov.pl/obszary-tematyczne/rynek-pracy/zasady-metodyczne-rocznik-pracy/rynek-pracyw-2017-r-,4,1.html (accessed 1 July 2019).

12. Labour Code (Kodeks pracy), Article 241.18.

13. Preventive meals are extra meals paid for by the employer.

14. Some of those interviews were conducted with support from the National Science Centre Poland (NCN), grant no. 2018/02/X/HS6/00957.

15. The IDI method was used. The research was carried out in 2018 and 2019 on 21 Uber drivers in Poland.

16. See https://zpp.net.pl/stanowisko-zpp-ws-projektu-ustawy-o-rynku-pracy-z-29-czerwca-2018-roku/ (accessed 1 July 2019).

17. Data from the register of multi-establishment collective labour agreements kept by the Ministry of the Family, Labour and Social Policy (end of July 2019).

18. Also known as certified translators.

19. At 7 September 2019.

20. See https://www.cbos.pl/SPISKOM.POL/2017/K_087_17.PDF (accessed 24 September 2019).

21. See https://www.wirtualnemedia.pl/ (accessed 10 February 2020).

22. See http://www.ozzip.pl/ (accessed 25 September 2019).

23. Ustawa z dnia 23 maja 1991 r. o rozwiązywaniu sporów zbiorowych, Dziennik Ustaw (Journal of Laws) of 1991, item 236.

24. Article 20 of the Act provides that a strike can be announced on condition that it is supported by the majority vote of at least 50 per cent of all employees in the workplace concerned.

25. See https://www.wirtualnemedia.pl/ (accessed 10 February 2020).

26. See https://www.wirtualnemedia.pl/ (accessed 10 February 2020).

27. This section is based on written answers, not interviews.

\section{BIBLIOGRAPHY}

Beck, U. (1992), Risk Society: Towards a New Modernity, Los Angeles, CA, London and New Delhi: Sage.

Czarzasty, J. (2019), 'Collective bargaining in Poland: a near-death experience', in T. Müller, K. Vandaele and J. Waddington (eds), Collective Bargaining in Europe: Towards an Endgame, vol. 2, Brussels: European Trade Union Institute, pp. 465-81.

Fedyuk, O. and M. Kindler (2016), Ukrainian Migration to the European Union, New York: Springer.

Grabowska-Lusińska, I., D. Drbohlav and A. Hars (eds) (2011) Immigration Puzzles: Comparative Analysis of the Czech Republic, Hungary and Poland before and after Joining the EU, Saarbrücken: Lambert Academic.

Grzymała-Kazłowska, A. (2013), 'Migration and socio-demographic processes in Central and Eastern Europe: characteristics, specificity and internal differences', Central and Eastern European Migration Review, 2 (1), 5-11. 
Kałuża-Kopias, D. (2014), 'Demograficzne skutki międzynarodowych migracji w wybranych krajach Unii Europejskiej ze szczególnym uwzględnieniem Polski', Studia Ekonomiczne. Zeszyty Naukowe Uniwersytetu Ekonomicznego w Katowicach, 167, 32-42.

Kostrzewa, Z. And G. Gudaszewski (2018), Informacja o rozmiarach i kierunkach emigracji z Polski w latach 2004-2017, Warsaw: GUS.

Lis, M. (2017), 'Za rok w Polsce będzie pracować 3 mln Ukraińców: Ich pensje rosną szybciej niż przeciętne', accessed 26 September 2019 at https://www.money.pl/gospodarka/unia-europejska/ wiadomosci/artykul/ukraincy-pracujacy-w-polsce-pensja-liczba,118,0,2381430.html.

Molodikova, I. and T. Yudina (2016), 'Migration strategies of Ukrainian migrants: EU or Russia', Contemporary Problems of Social Work: Bulletin of Chelyabinsk State University, 2 (3), 62-71.

National Labour Inspectorate (2016), 'Report on the activities of the National Labour Inspectorate 2002-2016', accessed 3 January 2020 at https://www.pip.gov.pl/pl/o-urzedzie/ sprawozdania-z-dzialalnosci/archiwum/2016.

National Labour Inspectorate (2017), 'Report on the activities of the National Labour Inspectorate in 2017', accessed 3 January 2020 at https://www.pip.gov.pl/pl/o-urzedzie/sprawozdania-zdzialalnosci/97255,sprawozdanie-glownego-inspektora-pracy-z-dzialalnosci-panstwowej-inspek cji-pracy-2017.html.

National Labour Inspectorate (2018), 'Report on the activities of the National Labour Inspectorate in 2018', accessed 3 January 2020 at https://www.pip.gov.pl/pl/o-urzedzie/sprawozdania-zdzialalnosci/104556,sprawozdanie-glownego-inspektora-pracy-z-dzialalnosci-panstwowej-inspek cji-pracy-2018.html.

Organisation for Economic Co-operation and Development (OECD) (2019), International Migration Outlook 2019, Paris: OECD.

Owczarek, D. and A Chełstowska (2016), Amazon po polsku. Warunki pracy $i$ stosunki z pracownikami, Warsaw: Instytut Spraw Publicznych.

Polkowska, D. and K. Filipek (2020), 'Grateful precarious worker? Ukrainian migrants in Poland', Review of Radical Political Economics, 52 (3), 564-81, doi:10.1177/0486613419857295.

Statistics Poland (2019), Labour Market in 2017, Warsaw, GUS. 